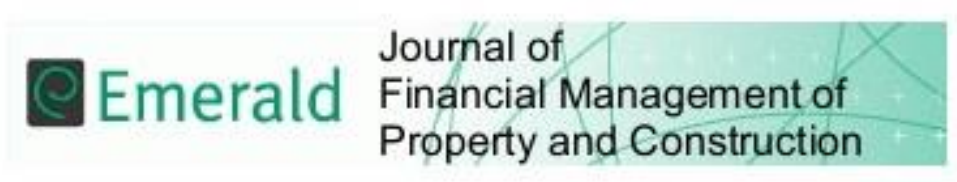

\title{
An investigation into BIM uptake among contracting firms: an empirical study in Nigeria
}

\begin{tabular}{|r|l|}
\hline Journal: & Journal of Financial Management of Property and Construction \\
\hline Manuscript ID & JFMPC-06-2019-0054.R2 \\
\hline Manuscript Type: & Research Paper \\
\hline Keywords: & $\begin{array}{l}\text { Building Information Modelling (BIM), Barriers, Evaluation of construction } \\
\text { companies, Construction Industry, Developing countries }\end{array}$ \\
\hline
\end{tabular}

\section{SCHOLARONE \\ Manuscripts}





\title{
An investigation into BIM uptake among contracting firms: an empirical study in Nigeria
}

\begin{abstract}
Purpose - Building Information Modeling (BIM) is vital in the performance improvement of contracting firms. Thus, there is a need to stimulate its implementation in the construction sector with a view to meeting the competitive demands of the industry. However, there have been very few studies on BIM implementation among contracting firms in Nigeria. Hence, this study examines the current BIM uptake among Nigerian contracting firms, assesses the barriers to BIM implementation, and examines ways of improving BIM implementation within these contracting firms.

Design/methodology/approach - A questionnaire survey was conducted on contracting firms (comprising small, medium and large sized firms) in Lagos, Nigeria. The obtained data were analyzed using both descriptive and inferential statistics. These included percentage, mean score, standard deviation, the Kruskal-Wallis test and factor analysis.

Findings - The study revealed the current state of BIM implementation among contracting firms in Nigeria in terms of their knowledge of BIM, their usage of BIM as well as the BIM software adopted. Furthermore, the study identified 25 barriers to BIM implementation in contracting firms and identified 15 ways to improve BIM implementation in contracting firms. The relative importance of both the identified barriers and the ways for improving BIM implementation was gauged among contracting firms comprising small, medium and large sized firms. The result of the Kruskal-Wallis test revealed that, except for two (out of 25) identified barriers, and one (out of 15) identified ways of improving BIM implementation in contracting firms, there is no significant statistical difference in the perceptions of the three respondents' groups. The result of the factor analysis categorized the identified 25 barriers into seven main factors.
\end{abstract}

Practical implications - The study provides empirical evidence on the barriers to BIM implementation and the ways of improving its implementation among contracting firms; thereby providing a better insight of the Nigerian construction industry's BIM environment.

Originality/value - The study's findings can positively inform the decisions of construction stakeholders to formulate strategies capable of improving BIM implementation in the construction industry at large.

Keywords: BIM, barriers, construction companies, construction industry, developing countries

Paper type: Research paper

\section{Introduction}

One of the largest industries known worldwide is the construction industry although, in terms of productivity, efficiency, quality and sustainability, it is still behind other industries. This is due to its inefficiency and a lack of production which have been ascribed to its composite nature of project delivery. Hence, it has faced many criticisms from across the world (Akintoye and Fitzgerald, 2000). An increase in production output can be linked to a better usage of information technologies (this factor can be ascribed to other industries as well as to the construction industry). The major source of concern for stakeholders in the construction industry is the need 
to increase productivity and returns on investments (ROIs) in construction project delivery. Additionally, there is poor communication between project stakeholders leading to a lack of efficiency and reduced output as a result of disintegration in the construction industry (Latham, 1994). Increased wastage, rework, time overruns, cost overruns and adversarial positions are common occurrence because of perceived or actual changes (resulting from the reduction in effectiveness) being nurtured by various factors in construction projects than for any other reason. Some other examples of problems within the construction industry are contractors who are aggressive threatening to slow down work or stop the work if they are not paid, clients claiming and insisting that extra conditions have been left out, expanded projects, and extra features which have to be covered by the original non-fluctuating bid price (Berger, 2008).

Increased productivity and coordination in the construction industry is imperative because the industry is becoming more complex and is taking longer to construct (Infocomm, 2011). The act of using computer-generated models to improve design and planning (among other aspects) in construction projects is known as BIM. Generally, all over the world, the uptake of BIM implementation in the construction industry is occurring rapidly. The design process as well as the construction of buildings is changing (Hassan and Yolle, 2009). Depending on agreement among the clients, manufacturers, contractors, architects, and engineers (including other consultants), BIM is seen as a new approach to design. However, Marderson et al. (2015) claimed that the implementation of BIM in the construction industry is still in its early stages despite its numerous advantages. This is affirmed by Cao et al. (2016) who stated that a large percentage of contracting firms are still in the early adoption stage. For instance, Forsythe (2014) argued that, in small firms, the low uptake of BIM implementation has been an issue. Yet there are a lot of studies focused on BIM implementation within large sized and large-scale projects (Forsythe, 2014; Rodgers et al., 2015). Additionally, challenges to BIM implementation in small and medium sized firms have received insufficient recognition in existing studies (Poirier et al., 2015). The fact that small and medium sized firms will continue to dominate the construction industry landscape far into the future makes studies on BIM within contracting companies of the utmost importance (Shelton et al., 2016).

In Nigeria, various studies on BIM have focused on awareness of BIM, adoption, benefits and challenges, both from the industry and academic perspectives (Ibironke et al., 2011; Abubakar et al., 2014; Marcus et al., 2015; Ugochukwu et al., 2015; Hamma-adama et al., 2017; Onungwa et al., 2017; Babatunde et al., 2018; Babatunde and Ekundayo, 2019). A few of these studies have examined the barriers to BIM implementation (see Abubakar et al., 2014; Babatunde and

Ekundayo, 2019). For instance, Abubakar et al. (2014) evaluated the perceptions of contractors on the factors influencing BIM in Nigeria. This study failed to evaluate the BIM barriers from the perceptions of each category of contracting firms (i.e. from small, medium and large sized firms). Babatunde and Ekundayo (2019) paid attention to the barriers to the incorporation of BIM into quantity surveying education from both academia and students' perspectives; hence the study (Babatunde and Ekundayo, 2019) did not examine the phenomenon from industry stakeholders' perspectives. Babatunde et al. (2019) went further to assess and compare the current levels of BIM maturity among AEC firms such as architectural, structural engineering, quantity surveying and facility management firms in Nigeria. However, this study only investigated the factors responsible for the different current BIM maturity levels exhibited by the identified AEC firms. Therefore, there is a need to critically investigate the current uptake of 
BIM implementation in the Nigerian construction industry. It against this backdrop that the following objectives are derived:

- To investigate the current uptake of BIM implementation among Nigerian contracting companies (comprising small, medium and large sized firms);

- To identify and examine the barriers to BIM implementation among the different Nigerian contracting company categories (i.e. among small, medium and large sized firms; and

- To investigate the ways of improving BIM implementation among the different Nigerian contracting company categories (i.e. among small, medium and large sized firms).

It is believed this study will provide a worthwhile insight into the Nigerian construction industry's BIM environment. The study findings should further inform the decisions of the construction stakeholders to make some policy recommendations capable of positively influencing full BIM implementation in the industry.

\section{Literature review}

\section{BIM implementation and the construction industry}

Fragmentation in the activities of the construction industry has been fuelled by both poor documentation and information management. The industry is characterized by low productivity and inefficiency as well as poor performance. For instance, Olatunji et al. (2010) argued that design errors and estimate deficiencies are some of the problems which reduce the flow of information throughout project life cycles. Several earlier studies have alluded to the need for an improved performance in the industry to deliver value for money and to effectively meet the needs of its clients. Against this backdrop, BIM is considered as the solution to some of these problems, even if not all, because it serves as a platform for consistent communication and collaboration among all construction stakeholders as well as having the capacity of bringing cleaniness into the design and construction processes leading to an improved general performance of the industry (Abubakar et al., 2014). BIM implementation has a lot of potential for improving the design, construction, and maintenance of buildings. This is corroborated by Eastman et al. (2011) who stated that the quality, efficiency and output of construction projects can be potentially increased by BIM. Furthermore, BIM gives a more comprehensive and accessible exposition of a building as well as giving more detailed and updated information. Several benefits are associated with BIM implementation on a construction project. These include, amongst others, the ability to ensure early joint decision-making, the clarity of better design, a stronger connection between the design and cost, virtual configurations and designs, better vision projections and simulations of best asset performance, reduced waste, merely minor errors in documentation, lower cost, better construction results, better predictions on performance outcomes, improved knowledge of the whole lifecycle, and data sharing among all the professionals from cradle to grave (Suermann, 2009; Azhar, 2011; Barlish and Sullivan, 2012; Hong et al., 2019). However, there are several socio-technical barriers which continually reduce the construction industry's ability to fully utilize the potentials of BIM despite its perceived benefits (Arayici, 2012; Bernstein and Pittman, 2014; Olawumi et al., 2017; Chan et al., 2019). In the Australian construction industry, Rodgers et al. (2015) claimed that about $45 \%$ of contracting firms have been using BIM in the South Australia compared to previous studies 
conducted around 2010 (see Gerrard et al., 2010). The rate at which BIM has been utilised in the Australian construction industry indicates the likely successful steps that the Australian contracting firms have taken to keep up with BIM trend. However, using integrated BIM with a satisfied level of collaboration from among stakeholders has remained a distant objective for the Australian contracting firms (Gerrard et al., 2010; Forsythe, 2014).

In Nigeria, however, the adoption of BIM is yet to be fully accepted in order to increase or enhance construction project delivery (Ibrahim and Bishir, 2012). The construction industry in Nigeria is slow to change and widely conservative. For example, building project delivery

methods and traditional procurement have remained the same for some decades. There has been a very slow move towards BIM adoption in Nigeria, both within the public (client side) and private sectors and among various construction professionals such as quantity surveyors, engineers and architects among others. A few architects have adopted BIM merely in order to enhance the visual quality of their presentations. And this is unfortunate because of its extraordinary potential to improve outputs and cost savings as well as curb corruption (Alufohai, 2012). Therefore, there is a need to stimulate its implementation in the construction industry, particularly among contracting firms, in order to meet the competitive demands in the industry. BIM can play a crucial role in performance improvement in contracting firms, but little has been done about its implementation among the contracting categories, particularly within developing countries.

\section{Overview of BIM implementation in the Nigerian construction industry}

The Nigerian construction industry is bedevilled by myriads of challenges such as cost overrun, time overrun, project abandonment, disputes, inefficiency and poor service delivery (Kolo and Ibrahim, 2010; Ameh, 2011; Ogwueleka, 2011; Babatunde et al., 2019). Therefore, there is a need for improved performance and efficiency in the Nigerian construction industry to deliver value for money and to effectively satisfy the needs of its clients. Hence, BIM is considered as the solution to some of these challenges, even if not all, because it serves as a platform for consistent communication and collaboration between all construction stakeholders as well as having the capacity of bringing cleaniness into the design and construction processes leading to an improved general performance of the construction industry in Nigeria (Abubakar et al., 2014). However, the extent of BIM adoption in Nigeria is best described as stagnant (Ibrahim and Bishir, 2012). For instance, Hamma-adama et al. (2017) stated that the current status of BIM uptake in Nigeria is predominantly by the usage of 2D and 3D. This is affirmed by Olugboyega and Aina (2018) who reported that both 2D and various variants of 3D BIM (such as 3D architectural model, 3D architectural and structural model and 3D architectural and building services model) are mostly used in Nigeria. Currently, BIM usage in Nigeria has been mostly requested by building owners and developers. The government at all levels (i.e. federal, state and local) is not showing much interest in the implementation of BIM for the delivery of public projects. This is contrary to the interest shown in BIM by governments in most developed countries. In the UK, for example, the government has made the usage of BIM compulsory on all public financed projects since 2016. Whilst in Australia and several European countries (such as the Netherlands, Norway, Spain, France and Germany among others) BIM has been increasingly used for many years because governments and several large public clients very often require the use of BIM in some or all their projects. It is on this premise that Alufohai (2012) asserted that 
the major driving force towards the higher utilization of BIM is governmental support. This assertion is also supported by Chan et al. (2019) in the case of Hong Kong.

Although, various studies have focused on the importance of BIM as a dependable instrument which can be used in the Nigerian construction industry, others have focused on the benefits of BIM in the Nigerian construction industry. For instance, Akerele and Etiene (2016) have assessed the level of BIM awareness and limitations within Nigeria. The authors found that the level of BIM awareness is generally low among professionals in the Nigerian construction

industry. This lack of awareness on the use of BIM is the major factor contributing to its low level of implementation. Additionally, there is a lack of support from the government for its full adoption in the Nigerian construction industry. Abubakar et al. (2014) evaluated the perceptions of contractors on the factors affecting BIM adoption in Nigeria and found, among other factors, that there is social and consistent resistance to change, a high cost of BIM software and a lack of an enabling environment in the form of government policies and legislation regarding BIM adoption. In all these previous studies, the focus has largely been on the level of BIM awareness, on BIM implementation, and on the benefits of BIM adoption among construction professionals. Although these previous studies have been of great help to know more about the current situation regarding BIM in Nigeria none has holistically investigated the current uptake of BIM implementation among contracting companies, comprising small, medium and large sized firms, or examined the barriers to BIM implementation among contracting company categories in the Nigerian construction industry.

\section{Barriers to BIM implementation in construction industry}

Despite the increasing awareness and perceived benefits of BIM, only two countries to date have more than a 50 percent adoption rate with the UK recording more than 55 percent and the USA with more than a 75 percent adoption rate, according to Olawumi et al. (2017). Various

viewpoints have been documented on most of the challenges that have contributed to the slow implementation of BIM in the construction industry (see Ghaffarianhoseini et al., 2017; Gerbov et al., 2018; Gamil, 2019; Georgiadou, 2019; Zhou et al., 2019 among others). These barriers can be classified into environmental, technological and organizational factors (Mahamadu, 2013). This categorization is consistent with a Technology, Organizational and Environmental (TOE) framework which has, in the past, been used in Information Technology (IT) studies in the categorization of factors of implementation (Tornatzky and Fleischer, 1990). Facilitating the ease of BIM implementation through software vendors, institutions of professionals, the market, and projects provided by government are mainly macro level facilitating conditions as well as all other issues are the environmental factors (Mahamadu, 2013; Sargent, 2012). All technical issues relating to the capabilities of BIM, including its characteristics, come under the technology factors. All the social stimuli of the technology adoption together with organizational elements which allude to internal organizational issues (i.e. the general form, raw materials, people and leadership) are the organizational factors (Davies and Hart, 2013; Mahamadu, 2013). Across the three elements of the construction industry, namely the supply chain, the organization and the project itself the major barriers that have been identified stem from the fact that the parties involved in the supply chain lack interest in BIM implementation. Additionally, there are negative mind sets regarding the huge effort and money that needs to be put in place for its implementation among the contracting firms. This implies that a lack of interest in accepting the 
risks that could accompany the return on interest (ROI) of BIM could be explained as the major barrier. This could be interpreted as the ROI received on investments in, and allocated resources to, BIM implementation could directly influence the level of BIM implementation undertaken by various decision makers (McGraw, 2014). Taking these risks by contracting firms which are still struggling for survival in the market can be said to be beyond an acceptable level. Naturally, contracting firms have a tendency to adopt previously-verified guaranteed ROI gained by reliable methods (Poirier et al., 2015a).

Within the organizational context/element factors such as inadequate knowledge, comfortability with current technologies, a lack of skill and expertise to adopt BIM, the cost of adoption, the high cost of training (among similar other factors on projects) can be ascribed to the lack of an organizational long term strategy or to the lack of an organizational structure within contracting firms (Poirier et al., 2015b). The efforts of policy makers and BIM advocates have to be focused on these two points (namely, the lack of an organizational long term strategy, and the lack of an organizational structure) in order to promote BIM implementation among contracting firms.

Azar (2012) stated that interoperability risks (i.e. between the different used programmes) are viewed as some of the crucial challenges in the adoption of BIM. When at the post contract stage of the project, this affects the arrangement of construction working drawings and restricts the use of BIM. However, even when each field works in a 3D environment, collaboration in Nigeria is still based on exchanging drawings in 2D (Khemlani, 2007). In Nigeria, the poor state of electricity and other infrastructure can be concluded as being an obstacle that affects the adoption of ICT in the Nigerian construction industry (Oladapo, 2007). Work in offices is affected by the constant lack of electricity and the lack of internet connectivity (Abubakir et al., 2014). While the adequate use of BIM requires full internet connection, the constant use of generators increases the cost of running offices because obtaining the BIM drawings requires internet connection. As a result of slow internet speeds, as well as issues with the supply of electricity, and because BIM systems require large files, it means that the administration, and conveying, of these records will not be easy to undertake in Nigeria (Abubakar et al., 2014). Despite these previous studies, Poirier et al. (2015a) argued that few studies have investigated the barriers to BIM implementation among small, medium and large sized firms.

Based on the foregoing, the identified barriers to BIM implementation in the construction industry have been summarized, and are presented in Table I as follows:

\section{>>>>>>>>>>>>>Insert Table $I>>>>>>>>>>$}

Similarly, the ways of improving BIM implementation in the construction industry that were identified by Kekana et al. (2015) and Ruya et al. (2018) have been adapted in this study. Since these studies were conducted in the South African and Nigerian construction industry respectively, hence the identified ways of improving BIM implementation were judged to be relevant in this study. These identified ways of improving BIM implementation were filtered to avoid duplication, and are presented in Table II.

>>>>>>>>>>>>> Insert Table II $>>>>>>>>>>$ 
Thus, this study empirically investigates the current uptake of BIM within the Nigerian small, medium and large contracting firms; examines the barriers to BIM implementation among contracting company categories in the Nigerian construction industry; and investigates the ways of improving BIM implementation among Nigerian contracting firm categories.

\section{Research methodology}

This study focused on BIM implementation within contracting companies comprising small, medium and large sized companies in Lagos, Nigeria. The choice of the study area was based on the premise that many construction companies are located in the area and thus this fact facilitated adequate data collection. In addition, a literature review was undertaken and the outcome revealed the 25 barriers to BIM implementation in the wider context (see Table I). Similarly, the review of the literature revealed the 15 ways of improving BIM implementation in the construction industry (see Table II). Therefore, both the identified barriers to BIM and the ways of improving BIM implementation were used to design a questionnaire survey. In order to capture the broad responses of the respondents from the different contracting firms' categories in the study area, a questionnaire survey was employed. Using a questionnaire survey is supported by many earlier researchers (see Blaxter et al., 2006). For instance, relevant previous studies on BIM have used a questionnaire survey. (For example, among others, Kekana et al. (2015) used a questionnaire survey when exploring BIM in the South Africa construction industry. Ruya et al. (2018) employed a questionnaire survey when assessing the challenges of BIM in the Nigerian construction industry. Olawumi and Chan (2019) used a questionnaire survey when developing a benchmark model for BIM implementation in developing countries). The data were obtained through a well-structured questionnaire distributed among contracting firms comprising small, medium and large sized firms in the study area. Among the sections of the questionnaire (for eliciting information) were the demographic profile of the respondents, the current state of BIM implementation among contracting firms, the BIM software in use by the respective firms' category, the barriers to BIM implementation among contracting categories, and the ways of improving BIM implementation among contracting categories.

The target population for this study was contracting firms comprising small, medium and large sized contracting firms in the study area. The total list of the aforementioned categories of contracting firms within the study area was extracted from the $5^{\text {th }}$ Procurement Journal of December 2016. Thereafter, a random sampling technique was adopted for the selection of the required number of respondents from both the small and medium contracting firms, and the total enumeration was employed for the large size firms; this resulted in a total of 236 contracting firms of varying sizes selected as the sample size in this study. Hence, a total of 236 questionnaires were self-distributed to the contracting firms of varying sizes in the study area, out of which a total of 85 questionnaires (representing 36\%) were completed and considered appropriate for the analysis. The response rate of $36 \%$ was above the $20-30 \%$ threshold considered to be adequate for questionnaire surveys in construction management studies (Akintoye, 2000; Akintoye and Fitzgerald, 2000; Dulaimi et al., 2003; Fellow and Liu, 2008). Therefore, the survey was adjudged to be free from non-respondent bias. The low response rate could be attributable to the tight schedule of the respondents and because they had also served as respondents to many other researchers in the study area. Despite the response rate, statistical analysis could still be conducted as the central limit theorem holds true with a sample size greater than 30 (Ling et al., 2004). 
The data obtained were analyzed using frequency, percentage, mean score, standard deviation, the Kruskal-Wallis test, and factor analysis. For instance, the Kruskal-Wallis test was undertaken to ascertain if there was a statistically significant difference in the ranking of both the 25 identified barriers to BIM implementation and the 15 identified ways of improving BIM implementation among the contracting firms comprising small, medium and large sized firms. The use of the Kruskal-Wallis test has been widely encouraged by earlier researchers when the samples are not less than three different groups with ordinal data (Fellows and Liu, 2008). Also, the factor analysis was carried out to identify a small number of factor categorizations (Pallant, 2010; Hair et al., 2010). Thus, the factor analysis was undertaken on the 25 identified BIM barriers to determine the underlying interactions or groupings that might exist between the identified BIM barriers.

\section{Results and discussion}

\section{Demographic profile of both the firms and respondents}

Table III shows the background profile of the firms and the respondents in relation to the categories of the firm, the numbers of employees, the specialty of the firms, the years of the firms' establishment, the major clients of the firms, the professional background of the respondents in their respective firms, the position of the respondents in their firms, and the highest academic qualification of the respondents. As indicated in Table III, the categories of the firm show that the small firms represented 41.18 percent, the medium firms represented 27.06 percent and the large firms represented 31.76 percent. The specialty of the firms revealed that a higher percentage of the firms focused on building works (with 58.82 percent), followed by engineering services' works (with 18.82 percent), while 3.53 percent of the firms were undertaking specialist works and 16.7 percent of the firms were involved in all the aforementioned works. The question on the major clients of the firms revealed that the government is the major client (with 42.35 per cent), followed by individual/owner (with 34.12 percent) while private organizations are 14.42 percent. The academic qualifications of the respondents revealed that the highest percentage of respondents' academic qualifications was at the BSc level (Bachelor's degree) (with 36.47 percent) followed by MSc (Master's degree) (with 22.35 percent) while 11.76 percent of the respondents had obtained a HND (Higher National Diploma) (see Table III for details).

\section{>>>>>>>>>>>>>>Insert Table III $>>>>>>>>>>>$}

\section{Current uptake of BIM implementation in the contracting firms}

This section shows the current uptake of BIM implementation among contracting firms in terms of their knowledge of BIM, usage of BIM, the type of projects BIM is being used for, as well as the BIM software adopted for use. Table IV indicates the knowledge of BIM as given by the respondents. It shows that 89.41 percent of the respondents have heard about BIM, while 10.59 percent of the respondents have not heard about BIM at all. Similarly, the question regarding knowledge of BIM revealed that the highest percentage of respondents with BIM knowledge were those who work in firms using BIM (with 53.95 percent) followed by those who read research relating to BIM (with 21.05 percent), and 17.11 percent of the respondents were those 
who were training on the usage of BIM (see Table IV for details). Table IV further reveals that 65.88 percent of the respondent firms have used BIM in some of their firm's projects, while 34.12 percent of the firms have not used BIM in any of their firms' projects. The respondents' responses on how their firms use BIM show that 36.47 percent of the firms use BIM often, 23.53 percent of the firms always uses BIM, while 34.12 percent of the firms have never used BIM (see Table IV for details). In addition, the respondents' selection of the types of project they used BIM for shows that 23.22 percent use BIM for educational buildings, 35.71 percent for residential projects, while 7.14 percent use BIM for public projects (see Table IV for details).

\section{>>>>>>>>>>>> Insert Table IV $>>>>>>>>>>$}

Moreover, regarding the BIM software adopted for use among the contracting firms, Figure I indicates that AutoCAD Architecture has the highest percentage of usage (with 20 percent) followed by Revit Architecture and ArchiCAD (with 15 percent each), while both Vela Field BIM and Nemmetschek Scia are not used at all, hence they have zero percent of usage (see Figure I for more details).

\section{>>>>>>>>>>>>>>Insert Figure I $>>>>>>>>>>$}

\section{Ranking of the barriers to BIM implementation among contracting firms}

Table V shows the ranking of the 25 identified barriers to BIM implementation among the small, medium and large contracting firms. In the ranking, attributes with the same mean value are ranked based on their standard deviation. In other words, an attribute with the lowest standard deviation is given a higher rank (Field, 2005). As shown in Table V, the results of the ranking of the 25 identified barriers to BIM implementation based on each contracting firm category are as follows:

Small contracting firms: The top five ranked barriers to BIM implementation from respondents in the small contracting firms are: the cost of the hardware and BIM software; BIM experts' shortage; difficulty in managing sophisticated data; weak cooperation among different professions, and the cost of BIM training, with the mean values of 4.48, 4.46, 4.46, 4.45 and 4.43 respectively.

Medium sized contracting firms: The top five ranked barriers in the medium sized contracting firms include: weak education and training; the cost of BIM software and its updates; problems relating to interoperability; issues of power supply and weak internet connectivity, and not knowing where to start, with their respective mean values of $4.59 ; 4.58 ; 4.54 ; 4.54$ and 4.54 respectively.

Large sized contracting firms: The top five ranked barriers to BIM implementation in the large sized contracting firms are: the cost of BIM training; the cost of BIM software and its updates; the cost of the hardware and BIM software; weak education and training, and not knowing where to start, with their mean values of $4.61,4.55,4.53,4.50$ and 4.48 respectively. 
Table $\mathrm{V}$ further reveals the total mean score values for the 25 identified barriers to BIM implementation among the small, medium and large contracting firms ranging from 4.06 to 4.51 (see Table V). It can be deduced that all the respondents considered these identified 25 barriers important. This is corroborated by Badu et al. (2012) who stated that a factor is important if it has a mean score value of 3.5 or above, based on a five point Likert scale. Thus, the top five ranked barriers to BIM implementation in contracting firms are: the cost of the hardware and BIM software; not knowing where to start; the cost of BIM software and its updates; problems relating to interoperability, and the cost of BIM training, with their respective total mean values of 4.51, 4.47, 4.46, 4.42 and 4.41 respectively. These study findings are slightly different from previous studies that found fear of change as one of the barriers to BIM implementation. For instance, Hassan and Yolles (2009) stated that most contracting firms find it difficult to change because they feel comfortable with the previous software that they have been using even though other software may be more advanced. It was found in this study's findings that a lack of awareness, and knowledge on BIM, are no longer a major barrier to BIM implementation in contracting firms. Thus, the major barriers to BIM implementation have shifted to the costrelated barriers among the contracting firms. This study, therefore, advocates that governments should encourage BIM implementation in the construction industry by making provision for adequate funds for training and the procurement of BIM software and hardware, including BIM upgrading, particularly in developing countries. In addition, the result of the Kruskal-Wallis test undertaken at a significance level of 5 percent showed that, except for 2 (out of 25) identified barriers, there are no significant statistical differences in the perceptions of the respondents in the three categories of contracting firms (comprising small, medium and large sized contracting firms). This shows that there is a common understanding of the barriers to BIM implementation among the contracting firms in Nigeria.

Ranking of the ways of improving BIM implementation among contracting firms Table VI indicates the ranking of the 15 identified ways of improving BIM implementation among contracting firms. Based on contracting firms' category, the findings are as follows:

Small contracting firms: The top five ranked ways of improving BIM implementation from the respondents in small contracting firms are: feasible ways of migrating from common practice into BIM; educating government departments on 'model based' deliverables and their benefits; BIM integration into education curricula; increase in the availability of BIM technology, and development of BIM forms of contract for stakeholders, with their mean values of 4.70, 4.68, 4.65, 4.65 and 4.60 respectively.

Medium sized contracting firms: The top five ranked ways of improving BIM implementation in medium sized contracting firms include: development of BIM intellectual property; BIM forms of contract development for stakeholders; improvement on BIM interoperability; organized BIM workshops for stakeholders, and government enforcement of BIM usage, with their respective mean values of 4.66, 4.66, 4.64, 4.63 and 4.61 respectively.

Large sized contracting firms: The top five ranked ways of improving BIM implementation in large sized contracting firms are: government enforcement of BIM usage; BIM skills' development programmes; educating government departments on 'model based' deliverables and their benefits; BIM integration into education curricula, and BIM forms of contract with insurance, with their respective mean values of 4.69, 4.67, 4.61, 4.57 and 4.52 respectively. 
>>>>>> > Insert Table VI $>>>>>>>>$

As further revealed in Table VI, the total ranking of the 15 identified ways of improving BIM implementation in contracting firms showed the total mean values ranging from 4.30 to 4.63 ; this signified that all the 15 identified ways of improving BIM implementation are considered important. In addition, the top five ranked ways of improving BIM implementation in contracting firms are: government enforcement of BIM usage; BIM integration into education curricula; BIM skills' development programmes; educating government departments on 'model based' deliverables and their benefits, and development of BIM warranty requirements, with their respective mean values of $4.63,4.61,4.60,4.56$ and 4.54 respectively. These findings affirm the existing literature. For instance, the UK BIM Strategy Report (2012) and BuildSmart (2012) reported that several governments in developed countries such as the United Kingdom, United States of America and Australia have mandated the usage of BIM on public-financed projects, which has led those countries to be the most recognized and leading countries in BIM implementation. Similarly, Han and Bedrick (2015) asserted that BIM implementation would suffer without its integration into education modules in higher education. Therefore, an emphasis should be placed on the need to incorporate BIM education into engineering, architecture, and quantity surveying programmes as well as within other construction related disciplines. Furthermore, the results of the Kruskal-Wallis test revealed that except for 1 (out of 15) identified ways of improving BIM implementation in contracting firms, there is no significant statistical difference in the perceptions of the three respondents' groups comprising small, medium and large contracting firms.

\section{Factor analysis on barriers to implementation of BIM in contracting firms}

Factor analysis was undertaken on the 25 identified barriers to BIM implementation among the contracting firms. After the data were obtained they were subjected to Kaiser-Meyer-Olkin (KMO) test and Bartlett's test of Sphericity. The results of the KMO value of 0.895 and Bartlett's test of Sphericity value of 0.000 imply that the data obtained was appropriate to undertake factor analysis (see Pallant, 2010). In addition, Field (2005) asserted that the communalities of the entire components greater than 0.50 are appropriate to conduct factor analysis. In this regard, communalities were conducted in this study. As depicted in Table VII, all the identified 25 barriers to BIM implementation among contracting firms in this study achieved communalities greater than 0.50 (see Table VII).

\section{>>>>>>> Insert Table VII $>>>>>>>>>$}

Regarding the sample size, several suggestions have been made on the most suitable sample size for factor analysis. For instance, Hinton et al. (2004) and Pallant (2007) recommended a minimum ratio of two responses for every item or variable. Hair et al. (2010) claimed that the sample size should be greater than 50 for factor analysis to be conducted. Thus, with the number of survey respondents being 85, this study is adjudged suitable for factor analysis. In this regard, the requirements for the KMO test, Barlett's test of Sphericity, communalities, and the sample size are all met. This justified that factor analysis is appropriate for this study. Thereafter, as shown in Table VIII, principal component analysis (PCA) and eigenvalue were used as decision criteria (see Pallant, 2010). For example, variables with an eigenvalue greater than 1.0 were considered in this study. 


\section{>>>>>>> Insert Table VIII $>>>>>>>>$}

Table VIII indicates the PCA results conducted on the 25 identified barriers to BIM implementation in contracting firms. As shown in Table VIII, the first seven components had eigenvalues greater than 1.0; thereby the seven factors were considered for the analysis. The total cumulative percentage of the extracted seven factors amounts to 65.517 percent.

In addition, Table IX reveals the principal factor extraction carried out on the 25 identified barriers to BIM implementation. As shown in Table IX, the seven extracted factors have the factor loadings between 0.496 and 0.826 ; hence all the variables are important in the analysis (see Kline, 2002; Brown, 2009).

\section{>>>>>>>Insert Table IX $>>>>>>>>$}

Thus, the seven extracted factors are named as follows:

Factor 1: Absence of BIM specialists, standards and protocols

Factor 2: Client related issues and high initial BIM outlay

Factor 3: Weak BIM skills and resistance to change

Factor 4: Cooperation issues with managing complicated data

Factor 5: Lack of BIM tangible benefits and intellectual property related issues

Factor 6: Non-governmental support and BIM working environment related issues

Factor 7: Interoperability issues

Factor 1: Absence of BIM specialists, standards and protocols: This factor amounts to 14.863 percent of the total variance of barriers to BIM implementation among contracting firms. This factor has five components which include: BIM experts' shortage; the amounts needed to be invested into applying BIM is not clear; insufficient BIM standards and protocols; the time frame of BIM application, and BIM design regulations' amendments. These components have high factor loadings: $0.795,0.728,0.702,0.674$ and 0.630 , respectively. This study's findings affirmed a few findings of the earlier studies. For instance, Saxon (2013) claimed that only a low number of BIM applications are available in developing countries because construction participants are yet to develop a capability to use BIM. Ezeokoli et al. (2016) stated that it is a mere illusion to desire the attainment of purposeful changes without procedures and regulations in place to implement it. Zahrizan et al. (2013) found that there are no general regulations regarding BIM implementation, thus each BIM user adopts their own principles without any directive from the vendor which will inevitably result in differences in the level of detail in the implementation in relation to various firms.

Factor 2: Client related issues and high initial BIM capital outlays: This factor amounts to 10.530 percent. This factor has five main components as follows: lack of BIM demand from clients; the cost of the hardware and the BIM software; the cost of BIM software and its updates; the cost of BIM training, and not knowing where to start. These components have factor loadings of $0.773,0.694,0.658,0.625$ and 0.598 , respectively (see Table IX). This study's findings reveal that there is no motivation for contracting firms to implement BIM as their clients do not request the use of BIM on their construction projects. It can be deduced that, in Nigeria, clients do not 
demand the use of BIM. This poses a great challenge to BIM implementation, resulting in a very low external force for its implementation. Hence, contracting firms become complacent and consider that BIM implementation is unimportant. This study's findings further confirmed some earlier studies that found that the major impediment to BIM implementation is the huge capital amount that is needed to be expended in setting up the model (which includes the procurement of BIM computer hardware and software packages, the cost of staff training, among other factors) (Young et al., 2008; Gardezi et al., 2014; Memon et al., 2014; Smith, 2014).

Factor 3: Weak BIM skills and resistance to change: This factor amounts to 9.583 percent. The four components are: a lack of BIM personnel and experts for training on the use of BIM software; the fact that BIM requires a complete change of practices and procedures; strong resistance to change, and weak skills among professionals and learning difficulties when learning to use BIM software. As indicated in Table IX, these components have the factor loadings 0.738 , $0.701,0.597$ and 0.538 respectively. This study's findings confirm the assertion of Nagalingam et al. (2013) that BIM is a new innovation, hence insufficient knowledge and skill relating to this new innovation becomes an impediment to BIM implementation. Kori and Arto (2015) opined that the attitude of construction professionals to change from an existing process to a new one poses more problems than the acquiring of skills. This is because the traditional method of procurement has been used so long that it is extremely difficult to embrace a new process. The delivery of most construction works in Nigeria has been paper-based and, therefore, the implementation of BIM will revolutionize the practices of construction professionals in the industry.

Factor 4: Cooperation issues with managing complicated data: This factor accounts for 9.039 percent (see Table VIII). The factor has three main components which are: weak cooperation among different professions; the need to manage sophisticated data with the BIM model, and a weak knowledge of BIM benefits. The three components have factor loadings of $0.826,0.674$, and 0.505 , respectively (see Table IX). These findings indicate that weak cooperation between different disciplines and the weak knowledge of BIM benefits go a long way in affecting BIM implementation among contracting firms.

Factor 5: Lack of BIM tangible benefits and intellectual property related issues: This factor amounts to 8.031 percent (see Table VIII). This factor has two components: the belief that there is no need for BIM application, and issues of intellectual property. The two components have factor loadings 0.807 and 0.571 , respectively (see Table IX). These findings indicate that contracting firms are reluctant to implement BIM because there is no clear policy that addresses the issue of intellectual property.

Factor 6: Non-governmental support and BIM working environment related issues: This factor amounts to 7.213 percent. This factor has three main components as follows: no government efforts to implement BIM, issues regarding power supply and weak internet connectivity, and weak education and training. The three components have factor loadings $0.701,0.602$ and 0.562 , respectively (see Table IX). These findings affirm the assertion of Smith (2014) who identified that a lack of 'push' via mandates from the government is an impediment to BIM implementation in the construction industry. Alufohai (2012) asserted that the extent of BIM implementation is relatively low in countries where there are no government policies in place to 
encourage BIM implementation. This finding found that the Nigerian government is not showing any interest in BIM implementation for the delivery of public projects. This particular study finding is contrary to the findings obtained in developed countries, where several governments in developed countries (such as the United Kingdom, United States of America and Australia among others) have set up strategies for the implementation of BIM in their construction works, which has led to rapid BIM implementation (Wong et al., 2009; BuildSmart, 2012; UK BIM Strategy Report, 2012). Similarly, the poor state of the electricity supply and other infrastructure is being identified as a significant obstacle in the Nigerian construction industry (Oladapo, 2007). For instance, the lack of constant electricity and the lack of internet connectivity automatically affect the full implementation of BIM, as BIM requires large files; thereby exchanging these files between those working on them poses a challenge in the Nigerian construction industry.

Factor 7: Interoperability issues: This factor amounts to 6.257 percent. This factor has only one component which is the problems relating to interoperability between BIM software packages. As shown in Table IX, this component has a factor loading of 0.697. This study finding has confirmed a similar finding in a few earlier studies. For instance, Boon (2009) opined that interoperability among the software of different developers is a factor that undermines BIM implementation. Azar (2012) claimed that interoperability risks are some of the crucial challenges in the implementation of BIM (between differently used programmes). Zulkipli and Lim (2015) identified a lack of standards relating to interoperability between software due to large data exchange.

\section{Conclusion}

BIM plays a crucial role in the performance improvement of contracting firms. There is, therefore, a need to stimulate its implementation in the construction industry, particularly among contracting firms so that they can meet the competitive demands of the construction industry. It is against this backdrop that this study examined the current uptake of BIM implementation among contracting firms in Nigeria (comprising small, medium and large contracting firms), assessed the barriers to BIM implementation in those contracting firms, and examined the ways of improving BIM implementation within those contracting firms. The study revealed the current state of BIM implementation among Nigerian contracting firms in terms of their knowledge of BIM, their usage of BIM as well as the BIM software adopted. Regarding the knowledge of BIM, the study found that 89.41 percent of the respondents' firms have heard about BIM, while 10.59 percent of the respondents' firms have not heard about BIM at all. The study found that 36.47 percent of the firms are using BIM often, 23.53 percent of the firms always use BIM, while 34.12 percent of the firms have never used BIM. Moreover, in relation to the BIM software adopted for use among the contracting firms, the study found that AutoCAD Architecture has the highest percentage of usage with 20 percent followed by Revit Architecture and ArchiCAD with 15 percent each.

In addition, the study identified 25 barriers to BIM implementation in contracting firms. The relative importance of these identified barriers was gauged among Nigerian contracting firms comprising small, medium and large contracting firms. The study revealed the top five ranked barriers to BIM implementation in contracting firms are as follows: the cost of the hardware and 
BIM software; not knowing where to start; the cost of BIM software and its updates; problems relating to interoperability, and the cost of BIM training. It is evident from these study findings that a lack of awareness of BIM is no longer a major barrier to BIM implementation in contracting firms. Thus, the major barriers to BIM implementation in contracting firms have shifted to cost and training related barriers. Similarly, the study identified 15 ways of improving BIM implementation in contracting firms. The study indicated the top five ranked ways of improving BIM implementation among contracting firms are: government enforcement of BIM usage; BIM integration into education curricula; BIM skills' development programmes; educating government departments on 'model based' deliverables and their benefits, and the development of BIM forms of contracts for stakeholders.

The study further revealed the Kruskal-Wallis test showed that only two (out of 25) identified barriers, and one (out of 15) identified ways of improving BIM implementation in contracting firms have a significant statistical difference in the rankings among the respondents' groups comprising small, medium and large contracting firms. This implies that there is a common understanding among the contracting firms' categories on both rankings (i.e. on the barriers and on the ways of improving BIM implementation). In addition, the study showed the result of factor analysis that categorized the 25 identified barriers into seven main factors: absence of BIM specialists, standards and protocols; client related issues and high initial BIM outlay; weak BIM skills and resistance to change; cooperation issues with managing complicated data; a lack of BIM tangible benefits and intellectual property related issues; non-governmental support and BIM working environment related issues, and interoperability issues. The study concluded that the awareness of BIM among Nigerian contracting companies is very high and that examining the current state of BIM among the contracting categories will enable the employers in these firms to understand how needful it is to encourage employees to improve their knowledge of BIM, and learn how to implement BIM, as well as advise clients on the benefits and importance of BIM in their projects so as to provide them with more value for their money. The study also concluded that there are ways of improving BIM implementation among contracting categories, thus contracting firms adhering to these ways will positively influence the improvement of BIM implementation in the Nigerian construction industry, and in the construction sector in developing countries at large.

Based on the findings emanating from this study, the following recommendations are proposed:

- There is a need for increased awareness of the benefits of BIM, particularly for public clients who have not shown much interest in the implementation of BIM for the delivery of public projects.

- There is also a need for well-trained professionals in the utilization of BIM in order to ensure increased knowledge of BIM in the Nigerian construction industry.

- There should be a full integration of BIM into the curricula of the architecture, engineering and construction disciplines in higher education institutions as a necessary step towards increased knowledge of BIM. This will ensure that graduates have the background knowledge of the concept, and implementation, of BIM. 
- The cost of BIM software should be reduced to a minimal cost and/or subsidised by the Nigerian government as this can also encourage users to learn more about BIM if the software is affordable.

- The government of developing countries should enforce the usage of BIM as a primary requirement in their construction industries.

\section{References}

Abubakar, M., Ibrahim, Y., Kado, D. and Bala, K. (2014), “Contractors' perception of the factors affecting building information modeling adoption in the Nigerian construction industry", In: International Conference on Computing in Civil and Building Engineering. Orlando, Florida, United States, June 23-25.

Akintoye, A. (2000), "Analysis of factors influencing project cost estimating practice", Construction Management and Economics, Vol.18 No.1, pp.77-89.

Akintoye, A. and Fitzgerald, E. (2000), "A survey of Current Cost Estimating Practices in the UK”, Construction Management and Economics, Vol.18 No.2, pp.161-172.

Alufohai, A. (2012), “Adoption of building information modeling and Nigeria's quest for project cost management", Journal of Nigerian institute of quantity surveyors, Vol.1 No.1, pp.610.

Arayici, Y., Coates, P., Koskela, L. and Kagioglou, M. (2012), BIM Adoption and Implementation for Architectural Practices, Prentice Hall, London.

Autodesk (2011), Realizing the benefits of BIM, Autodesk Building Information Modeling, available at: http://www.autodesk.com/bim (accessed 12 August 2018).

Azhar, S. (2011), "Building information modeling (BIM): trends, benefits, risks, and challenges for the AEC industry", Leadership and Management in Engineering, Vol.11 No.3, pp.241-252.

Azhar, S., Khalfan, M. and Maqsood, T. (2015), "Building information modeling: now and beyond", Construction Economics and Building, Vol.12 No.4, pp.15-28.

Babatunde, S. O. and Ekundayo, D. (2019), "Barriers to the incorporation of BIM into quantity surveying undergraduate curriculum in the Nigeria universities", Journal of Engineering, Design and Technology, Vol.17 No.3, pp.629-648.

Babatunde, S. O., Ekundayo, D., Babalola, O. and Jimoh, J. A. (2018), “Analysis of the drivers and benefits of BIM incorporation into quantity surveying profession: Academia and students' perspectives", Journal of Engineering, Design and Technology, Vol.16 No.5, 750-766.

Babatunde, S. O. (2015), "Developing public private partnership strategy for infrastructure delivery in Nigeria", Doctoral thesis, Northumbria University, UK. 
Babatunde, S .O., Ekundayo, D. and Adekunle, A. O. (2019), "Analysis of BIM maturity level among AEC firms in developing countries: a case of Nigeria", In: 35th Annual ARCOM Conference. Leeds Beckett University, Leeds, UK, September 2-4, pp 225-234.

Badu, E., Edwards, D. J., Owusu-Manu, D. and Brown, D. M. (2012), "Barriers to the implementation of innovative financing (IF) of infrastructure", Journal of Financial Management of Property and Construction, Vol. 17 No. 3, pp. 253-273.

Barlish, K. and Sullivan, K. (2012), "How to measure the benefits of BIM - a case study approach", Automation in Construction, Vol. 24 No.1, pp.149-159.

Bernstein P. G. and Pittman J. H. (2014), "Barriers to the adoption of building information modeling in the building industry", Autodesk Building Solutions White Paper.

Blaxter, L., Hughes, C. and Tight, M. (2006), How to research, Open University Press, Maidenhead.

Boon, J. (2009), "Preparing for the BIM revolution", In: 13th Pacific Association of Quantity Surveyors Congress (PAQS), pp.33-40.

Brown, J. D. (2009), "Choosing the right type of rotation in PCA and EFA," JALT Testing and Evaluation SIG Newsletter, Vol.13 No.3, pp.20-25.

buildingSMART Australasia (2012), "National building information modeling initiative report", available at: www.innovation.gov.au/Industry/BuildingandConstruction/BEIIC/Documents/NBIMIRe port.pdf (accessed 22 April 2019).

Cao, D., Li, H., Wang, G. and Huang, T. (2016), "Identifying and contextualizing the motivations for BIM implementation in construction projects: an empirical study in China", International journal of project management.

Chan, D. W. M., Olawumi, T. O. and Ho, A. M. L. (2019), “Critical Success Factors for Building Information Modelling (BIM) Implementation in Hong Kong", Engineering, Construction and Architectural Management, Vol.26 No.9, pp.1838-1854.

Dulaimi, M. T., Ling, F. Y. Y., and Bajracharya, A. (2003), “Organisational motivation and inter-organisational interaction in construction innovation in Singapore", Construction Management and Economics, Vol.21, pp.307-318.

Eastman, C., Teicholz, P., Sacks, R. and Liston, K. (2011), BIM Handbook: A Guide to Building Information Modeling for Owners, Managers, Designers, Engineers, and Contractors, John Wiley \& Sons Inc, New Jersey, USA.

Ezeokoli, F. O., Okoye, P. U. and Nkeleme, E. (2016), "Factors affecting the adaptability of building information modeling for construction projects in Anambra state Nigeria", Journal of Scientific Research \& Reports, Vol.11 No.5, pp.1-10.

Fellows, R. R. and Liu, A. (2008), Research Methods for Construction, Wiley-Blackwell Science, London.

Field, A. (2005), Discovering Statistics using SPSS, Sage, London.

Forsythe, P. (2014), "The case for BIM uptake among small construction contracting businesses", In: The 31st International Symposium on Automation and Robotics in 
Construction and Mining. University of Technology Sydney, Sydney, Australia, June 2325.

Gamil, Y. (2019), "Awareness and challenges of building information modelling (BIM) implementation in the Yemen construction industry", Journal of Engineering, Design and Technology, Vol.17 No.5, pp.1077-1084.

Gardezi, S. S., Shafiq, N., Faris, M. and Khamidi, B. (2014), "Prospects of building information modeling in Malaysian construction industry as conflict resolution tool", Journal of Energy Technologies and Policy, Vol.3 No.11, pp.346-350.

Georgiadou, M. C. (2019), “An Overview of Benefits and Challenges of Building Information Modelling (BIM) Adoption in UK Residential Projects", Construction Innovation, Vol.19 No.3, pp.298-320.

Gerbov, A., Singh, V. and Herva, M. (2018), "Challenges in applying design research studies to assess benefits of BIM in infrastructure projects: Reflections from Finnish case studies", Engineering, Construction and Architectural Management, Vol.25 No.1, pp.2-20.

Gerrard, A., Zuo, J., Zillante, G. and Skitmore, M. (2010), "Building information modeling in the Australian architecture engineering and construction industry", In: U. Jason and I. Umit eds. Handbook of Research on Building Information Modeling and Construction Informatics: Concepts and Technologies, IGI Global, Hershey, PA, USA. pp.521-545.

Ghaffarianhoseini, A., Tookey, J., Ghaffarianhoseini, A., Naismith, N., Azhar, S., Efimova, O. and Raahemifar, K. (2017), "Building Information Modelling (BIM) uptake: Clear benefits, understanding its implementation, risks and challenges", Renewable and Sustainable Energy Reviews, Vol.75, pp.1046-1053.

Hair, J. F., Black, W. C., Babin, B. J. and Anderson, R. E. (2010), Multivariate Data Analysis: A Global Perspective, Pearson, Upper Saddle River, NJ, London.

Hamma-adama, M., Salman, H. S. and Kouider, T. (2017), "Diffusion of innovations: the status of building information modeling uptake in Nigeria", Journal of Scientific Research and Reports, Vol.17 No.4, pp.1-12.

Hong, Y., Hammad, A. W., Sepasgozar, S. and Akbarnezhad, A. (2019), "BIM adoption model for small and medium construction organisations in Australia", Engineering, Construction and Architectural Management, Vol.27 No.2, pp.154-183.

Ibironke, O. T., Ekundayo, D. and Awodele, O. A. (2011), "A survey on the use and impact of information technology in quantity surveying service delivery in Nigeria", In: 27th Annual ARCOM Conference. University of the West of England, Bristol, UK, September 5-7, pp 433-442.

Ibrahim, S. and Birshir I. (2012), "Review of using building information modeling in Nigerian construction industry", Journal of Environmental Sciences and Policy Evaluation, Vol.2 No.2, pp.52-62.

Infocomm (2011), Building information modeling, Infocomm International, Fairfax, Virgin.

Kekana, G., Aigbavboa, C. and Thwala, W. (2015), "Understanding building information modeling in the South Africa construction industry", OTMC Conference 2015. 
Khemlani, L. (2007), “Top criteria for BIM solutions”, available at: AECbytes 'http://www.aecbtes.com/feature/2007/BIMSurveyReport.htm (accessed 16 May 2019).

Khosrowshahi, F. and Arayici, Y. (2012), "Roadmap for implementation of BIM in the UK construction industry", Engineering, Construction and Architectural Management, Vol.19 No.6, pp.610-35.

Kline, P. (2002), An Easy Guide to Factor Analysis, Routledge, London.

Kori, S.A., Arto, K. (2015), Toward adoption of BIM in the Nigerian AEC industry; context framing, data collecting and paradigm for interpretation. Paper presented at the $9^{\text {th }}$ BIM Academic Symposium \& Job Task Analysis Review, NIBS-Washington DC, USA. Retrieved from http://livrepository.liverpool.ac.uk/id/eprint/2007727. (Accessed 12, August, 2018).

Latham, M. (1994), Constructing the team. Joint Review of Procurement and Contractual Arrangement in the UK Construction Industry.

Ling, F. Y. Y., Chan, S. L., Chong, E. and Ee, L. P. (2004), "Predicting performance of designbuild and design-bid-build projects", Journal of Construction Engineering and Management, Vol.130 No.1, pp. 75-83.

Liu, R., Issa, R. and Olbina. S. (2010), "Factors influencing the adoption of building information modelling in the AEC Industry", available at: http://www.engineering.nottingham.ac.uk/icccbe/proceedings/pdf/pf70.pdf (accessed 16 December 2018).

Mahamadu A. (2013), Challenges to digital collaborative exchange for unsustainable project delivery through building information modeling technologies. Proceedings of 8th International Conference on Urban Regeneration and Sustainability, pp.547-557.

Manderson, A., Jefferies, M. and Brewer, G. (2015), "Building information modeling and standardized construction contracts", Construction Economics and Building, 77-84.

McGraw Hill, (2014), The business value of BIM in Australia and New Zealand: how building information modeling is transforming the design and construction industry, McGraw Hill Construction, Bedford, MA.

Memon, A. H., Rahman, I. A., Memon I. and Azman, N. A. (2014), "BIM in Malaysian construction industry: status, advantages, barriers and strategies to enhance the implementation level", Research Journal of Applied Sciences, Engineering and Technology, Vol.8 No.5, pp.606-614.

Nagalingam, G., Jayasena, H. S. and Ranadewa, K. A. (2013), "Building information modelling and future quantity surveyor's practice in Sri Lankan construction industry”, The Second World Construction Symposium, Socio-Economic Sustainability in Construction, Colombo, Sri Lanka, pp.81-92.

Oladapo A. A. (2007), "An investigation into the use of ICT in the Nigerian Construction Industry", ITcon: Construction information technology in emerging economies, Vol. 12, pp.262-277. 
Olatunji, O. A., Sher, W. and Gu, N. (2010), "Building information modelling and quantity surveying practice", Emirates Journal for Engineering Research, Vol.15 No.1, pp.67-70.

Olawumi, T. O. and Chan, D. W. M. (2019), "Development of a benchmarking model for BIM implementation in developing countries", Benchmarking: An International Journal.

Olawumi, T. O., Chan, D. W. M. and Wong, J. K. W. (2017), "Evolution in the intellectual structure of BIM research: a bibliometric analysis", Journal of Civil Engineering and Management, Vol.23 No.8, pp.1060-1081.

Onungwa, I. O., Uduma-Olugu, N. and Igwe, J. M. (2017), "Building information modeling as a construction management tool in Nigeria", WIT Transactions on the Built Environment, Vol.169, pp.25-33.

Pallant, J. (2010), SPSS Survival Manual: A Step to Step Guide to Data Analysis Using SPSS for Windows, Open University Press.

Poirier, E., Staub-French, S. and Forgues, D. (2015a), "Embedded contexts of innovation: BIM adoption and implementation for a specialty contracting SME”, Construction Innovation, Vol.15 No.1, pp.42-65.

Poirier, E.A., Staub-French, S. and Forgues, D. (2015b), "Assessing the performance of the building information modeling implementation process within a small specialty contracting enterprise", Canadian Journal of Civil Engineering, Vol. 42 No.10, pp.766778

Rodgers, C., Hosseini, M. R., Chileshe, N. and Rameezdeen, R. (2015), "BIM within the Australian construction related small and medium sized enterprises: awareness, practices and drivers", In: A.B. Raidén, E, Proceedings 31st Annual ARCOM Conference, ARCOM, Lincoln, UK.

Ruya T. F., Chitumu Z. D. and Kaduma, L. A. (2018), "Challenges of building information modeling implementation in Africa: a case of Nigerian construction industry", FIG Congress 2018 Embracing our smart world where the continents connect: enhancing the geospatial maturity of societies, May 6-11, 2018, Istanbul, Turkey.

Shelton, J., Martek, I. and Chen, C. (2016), "Implementation of innovative technologies in smallscale construction firms: five Australian case studies", Engineering, Construction and Architectural Management, Vol.23 No.2, pp.177-191.

Smith, P. (2014), "Project cost management with 5D BIM", Procedia - Social and Behavioral Sciences, Vol.226, pp.193-200.

Suermann, P.C. (2009), Evaluating the impact of building information modelling (BIM) on construction. Doctoral dissertation, University of Florida.

Trochim, W. (2000), The Research Methods Knowledge Base, $2^{\text {nd }}$ Edition. Atomic Dog Publishing, Cincinnati, $\mathrm{OH}$.

Ugochukwu, S. C., Akabogu, S. C. and Okolie, K. C. (2015), "Status and perceptions of the application of building information modeling for improved building projects delivery in Nigeria", American Journal of Engineering Research, Vol.4 No.11, pp.176-182. 
UK BIM Strategy Report (2012), Industrial Strategy: Building Information Modeling, Industrial Strategy: Government and Industry in Partnership, Her Majesty Government, London.

Winch, G. (1998), "Zephyrs of creative destruction: understanding the management of innovation in construction”, Building Research \& Information, Vol.26 No.5, pp.268-279.

Wong, A., Wong, F. and Nadeem, A. (2009), Comparative roles of major stakeholders for the implementation of BIM in various countries, Hong Kong Polytechnic University, Hong Kong.

Young, N. W., Jones, S. A. and Bernstein, H. M. (2008), Building information modeling transforming design and construction to achieve greater industry productivity. McGrawHill Construction.

Zahrizan Z., Ali, N. M., Haron, A. T., Marshall-Ponting, A. and Hamid Z.A. (2013), "Exploring the adoption of building information modeling in the Malaysian construction industry: a qualitative approach", International Journal of Research in Engineering and Technology, Vol.2 No.8, pp.384-395.

Zhou, Y., Yang, Y. and Yang, J. (2019), "Barriers to BIM Implementation Strategies in China", Engineering, Construction and Architectural Management, Vol.26 No.3, pp.554-574. 


\section{List of Figure}

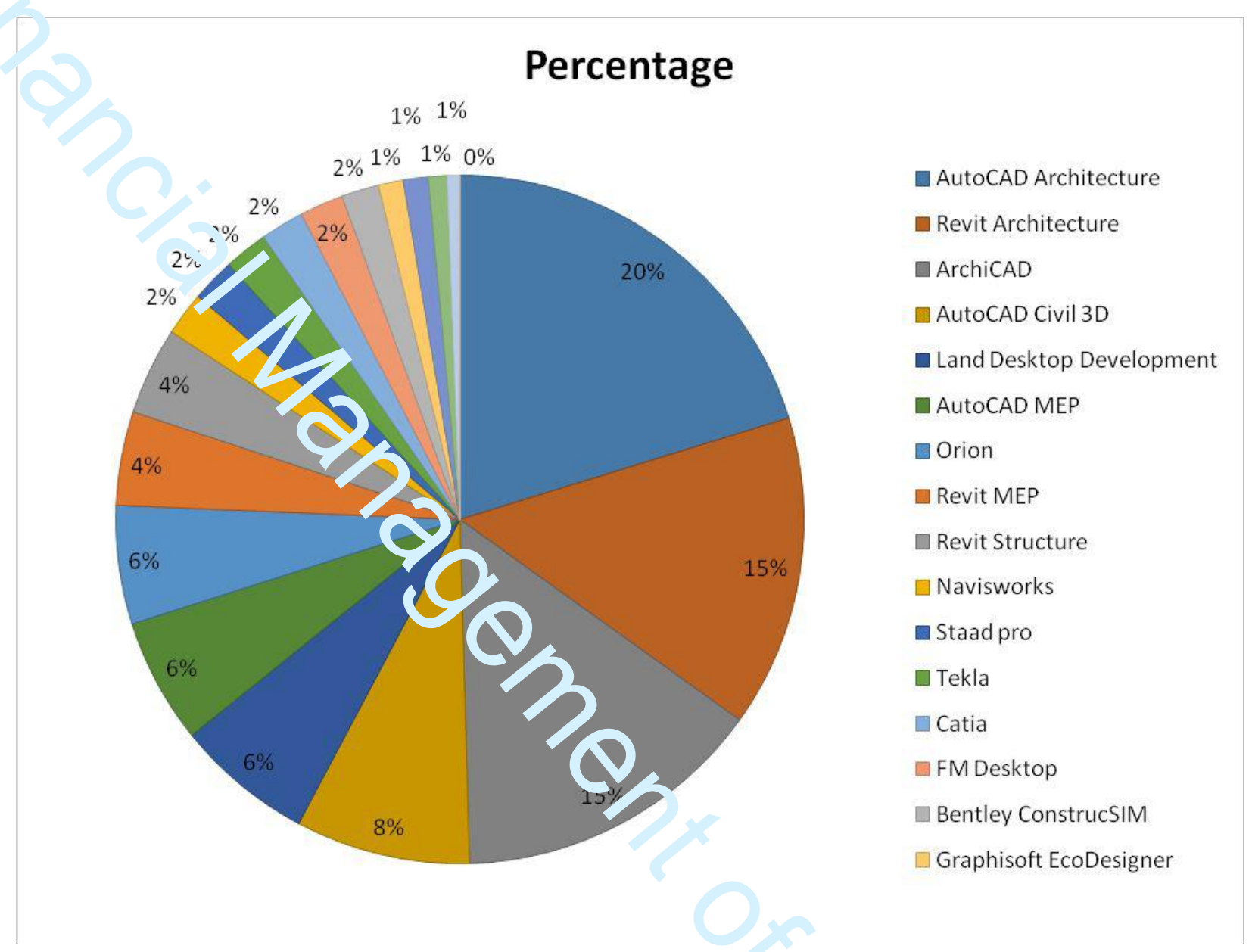

Figure I: BIM software in use within contracting firms 


\section{List of Tables}

Table I: Identified barriers to BIM implementation in the construction industry

\begin{tabular}{|c|c|c|}
\hline Code & BIM barriers & Reference \\
\hline $\mathrm{B} 01-$ & Lack of BIM demand from clients & $\begin{array}{l}\text { Khosrowshahi and Arayici, 2012; ; Chan, 2014; Azhar et } \\
\text { al., 2015; Poirier et al., 2015a; Rodgers et al., } 2015\end{array}$ \\
\hline B02 & Cost of BIM software and its updates & $\begin{array}{l}\text { Gerrard et al., 2010; Khosrowshahi and Arayici, 2012; } \\
\text { Abubakar et al., 2014; Forsythe,2014; Azhar et al., 2015; } \\
\text { Rodgers et al., } 2015\end{array}$ \\
\hline B03 & Cost of the hardware and BIM software & $\begin{array}{l}\text { Ugochukwu et al., 2015; Kekana et al., 2015; Ruya et } \\
\text { al.,2018 }\end{array}$ \\
\hline B04. & Cost of BIM training & $\begin{array}{l}\text { Khosrowshahi and Arayici, 2012; Rodgers et al., 2015; } \\
\text { Ruya et al.,2018 }\end{array}$ \\
\hline B05 & $\begin{array}{l}\text { Cost of BIM specialists and additional staff } \\
\text { recruitment }\end{array}$ & $\begin{array}{l}\text { Khosrowshahi and Arayici, 2012; Abubakar et al., 2014; } \\
\text { Rodgers et al., } 2015\end{array}$ \\
\hline B06 & Time frame of BIM application & Kekana et al., 2015; Ruya et al.,2018 \\
\hline B07 & $\begin{array}{l}\text { Investment is not clear from the BIM } \\
\text { application }\end{array}$ & Kekana et al., 2015; Poirier et al., 2015b; Ruya et al.,2018 \\
\hline B08 & BIM experts' shortage & $\begin{array}{l}\text { Gerrard et al.,2010; Chan, 2014; Azhar et al., 2015; } \\
\text { Kekana et al., 2015; Rodgers et al., } 2015\end{array}$ \\
\hline B09 & Insufficient BIM standards and protocols & Kekana et al., 2015; Ruya et al.,2018 \\
\hline B10 & $\begin{array}{l}\text { Belief that there is no need for BIM } \\
\text { application }\end{array}$ & Khosrowshahi and Arayici, 2012; Forsythe, 2014 \\
\hline B11 & Interoperability issues & $\begin{array}{l}\text { Khosrowshahi and Arayici, 2012; Forsythe, 2014; Azhar } \\
\text { et al., } 2015\end{array}$ \\
\hline B12 & Weak education and training & Azar, 2011; Ruya et al.,2018 \\
\hline B13 & No government efforts to implement BIM & Hassan and Yolles, 2009 \\
\hline B14 & Difficulty in managing sophisticated data & Poirier et al., 2015a \\
\hline $\begin{array}{l}\text { B15 } \\
\text { B16 }\end{array}$ & $\begin{array}{l}\text { Weak cooperation among different professions } \\
\text { Issues of intellectual property }\end{array}$ & $\begin{array}{l}\text { Poirier et al., 2015a; Ruya et al.,2018 } \\
\text { Khosrowshahi and Arayici, 2012; Azhar et al., 2015; } \\
\text { Kekana et al., 2015 }\end{array}$ \\
\hline B17 & BIM design regulations amendment & Poirier et al., 2015 b; Ruya et al.,2018 \\
\hline B18 & Development of BIM forms of contract & Kekana et al., 2015; Ruya et al.,2018 \\
\hline B19 & Weak knowledge of BIM benefits & Khosrowshahi and Arayici, 2012; Abubakar et al., 2014; \\
\hline B20 & $\begin{array}{l}\text { Weak skills among professionals and learning } \\
\text { difficulty of BIM software }\end{array}$ & Kekana et al., 2015; Ruya et al.,2018 \\
\hline B21 & $\begin{array}{l}\text { Lack of BIM personnel and experts for } \\
\text { training BIM software }\end{array}$ & Khosrowshahi and Arayici, 2012; Abubakar et al., 2014; \\
\hline B22 & $\begin{array}{l}\text { Issues of power supply and weak internet } \\
\text { connectivity }\end{array}$ & $\begin{array}{l}\text { Rodgers et al., } 2015 \\
\text { Oladapo, 2007; Abubakar et al., 2014; Ruya et al.,2018 }\end{array}$ \\
\hline B23 & Strong resistance to change & $\begin{array}{l}\text { Abubakar et al., 2014; zhar et al., 2015; Kekana et al., } \\
\text { 2015; Rodgers et al.. 2015; Ruya et al.,2018 }\end{array}$ \\
\hline B24 & $\begin{array}{l}\text { BIM requires a complete change of practices } \\
\text { and procedures }\end{array}$ & Kekana et al., 2015; Ruya et al.,2018 \\
\hline B25 & Not knowing where to start & $\begin{array}{l}\text { Gerrard et al.,2010; Forsythe,2014; Azhar et al., 2015; } \\
\text { Ruya et al.,2018 }\end{array}$ \\
\hline
\end{tabular}


Table II: Identified ways of improving BIM implementation in the construction industry

\begin{tabular}{cl}
\hline Code & Ways of improving BIM implementation \\
\hline W01. & BIM integration into education curricula \\
W02 & BIM skills development programs \\
W03 & Feasible ways of migrating from common practice into BIM \\
W04 & Increase the availability of BIM technology \\
W05 & Organized BIM workshops for stakeholders \\
W06 & Undertake pilot projects to validate and demonstrate the BIM benefits \\
W07 & Improvement on BIM interoperability \\
W08 & Communicate lessons learnt from the pilots projects to all stakeholders \\
W09 & Development of BIM forms of contract for stakeholders \\
W10 & Development of BIM intellectual property \\
W11 & Improvement on BIM software standardization \\
W12 & BIM forms of contract with insurance \\
W13 & Educate government departments on 'model based' deliverables and its \\
& benefits \\
W14 & Development of BIM warranty requirements \\
W15 & Government enforcement of BIM usage \\
\hline
\end{tabular}


Table III: Demographic profile of both the firms and respondents

\begin{tabular}{|c|c|c|c|}
\hline Profile & Frequency & Percentage & $\begin{array}{l}\text { Cumulative } \\
\text { percentage }\end{array}$ \\
\hline \multicolumn{4}{|l|}{ Categories of the firm } \\
\hline Small & 35 & 41.18 & 41.18 \\
\hline Medium & 23 & 27.06 & 68.24 \\
\hline Large & 27 & 31.76 & 100.00 \\
\hline Total & 85 & 100.00 & \\
\hline \multicolumn{4}{|l|}{ Numbers of employees } \\
\hline Small (10-50) & 44 & 51.76 & 51.76 \\
\hline Medium (51-250) & 21 & 24.71 & 76.47 \\
\hline Large (251 and above) & 20 & 23.53 & 100.00 \\
\hline Total & 85 & 100.00 & \\
\hline \multicolumn{4}{|l|}{ Specialty of the firm } \\
\hline Building works & 50 & 58.82 & 58.82 \\
\hline Civil engineering works & 16 & 18.82 & 77.64 \\
\hline Engineering services works & 2 & 2.35 & 79.99 \\
\hline Specialist works & 3 & 3.53 & 83.52 \\
\hline All of the above & 14 & 16.47 & 100.00 \\
\hline Total & 85 & 100.00 & \\
\hline \multicolumn{4}{|l|}{ Year of firms' establishment } \\
\hline Up to 10 years & 46 & 54.12 & 54.12 \\
\hline $11-20$ years & 27 & 31.76 & 85.88 \\
\hline More than 20 years & 11 & 12.94 & 98.82 \\
\hline Others & 1 & 1.18 & 100.00 \\
\hline \multicolumn{4}{|c|}{100.00} \\
\hline \multicolumn{4}{|l|}{ Firms' major client } \\
\hline Government & 36 & 42.35 & 42.35 \\
\hline individual/owner & 29 & 34.12 & 76.47 \\
\hline Private organization & 12 & 14.12 & 90.59 \\
\hline Others & 8 & 9.41 & 100.00 \\
\hline Total & 85 & 100.00 & \\
\hline \multicolumn{4}{|c|}{ Respondents' professional background } \\
\hline Architect & 29 & 34.12 & 34.12 \\
\hline Engineer & 23 & 27.06 & 61.18 \\
\hline Quantity Surveyor & 20 & 23.53 & 84.71 \\
\hline Others & 13 & 15.29 & 100.00 \\
\hline Total & 85 & 100.00 & \\
\hline
\end{tabular}


Position of respondents

Director

Designer

Project manager

Engineer

Others

Total

Respondents' highest academic qualification

OND (Ordinary National Diploma)

HND (Higher National Diploma)

PGD (Post Graduate Diploma)

BSc

MSc

$\mathrm{PhD}$

Others

Total

\begin{tabular}{|c|c|c|}
\hline Frequency & Percentage & $\begin{array}{l}\text { Cumulative } \\
\text { percentage }\end{array}$ \\
\hline 2 & 2.35 & 2.35 \\
\hline 24 & 28.24 & 30.59 \\
\hline 23 & 27.06 & 57.65 \\
\hline 3 & 3.53 & 61.18 \\
\hline 33 & 38.82 & 100.00 \\
\hline 85 & 100.00 & \\
\hline 6 & 7.06 & 7.06 \\
\hline 15 & 17.65 & 24.71 \\
\hline 10 & 11.76 & 36.47 \\
\hline 31 & 36.47 & 72.94 \\
\hline 19 & 22.35 & 95.29 \\
\hline 1 & 1.18 & 96.47 \\
\hline 3 & 3.53 & 100.00 \\
\hline 85 & 100.00 & \\
\hline
\end{tabular}


2 3

Table IV: Current state of BIM implementation among contracting firms

\begin{tabular}{|c|c|c|c|}
\hline & Frequency & Percentage & $\begin{array}{l}\text { Cumulative } \\
\text { percentage }\end{array}$ \\
\hline \multicolumn{4}{|l|}{ Have you ever heard about BIM } \\
\hline Yes & 76 & 89.41 & 89.41 \\
\hline No & 9 & 10.59 & 100.00 \\
\hline Total & 85 & 100.00 & \\
\hline \multicolumn{4}{|l|}{ If yes above, please select a paragraph } \\
\hline Worked in firms using BIM & 41 & 53.95 & 53.95 \\
\hline Read researches related to BIM & 16 & 21.05 & 75.00 \\
\hline I am training on the use of BIM & 13 & 17.11 & 92.11 \\
\hline Participated in conferences related to BIM & 5 & 6.58 & 98.69 \\
\hline Part dealt with in my university & 1 & 1.31 & 100.00 \\
\hline Total & 76 & 100.00 & \\
\hline \multicolumn{4}{|c|}{ Have you used BIM in any of your firms' project } \\
\hline Yes & 56 & 65.88 & 65.88 \\
\hline No & 29 & 34.12 & 100.00 \\
\hline Total & 85 & 100.00 & \\
\hline \multicolumn{4}{|l|}{ How often does your firm uses BIM } \\
\hline Always & 20 & 23.53 & 23.53 \\
\hline Often & 31 & 36.47 & 60.00 \\
\hline Once in a while & 5 & 5.88 & 65.88 \\
\hline Never & 29 & 34.12 & 100.00 \\
\hline Total & 85 & 100.00 & \\
\hline \multicolumn{4}{|l|}{ Type of project used BIM for } \\
\hline Educational & 13 & 23.22 & 23.22 \\
\hline Residential & 20 & 35.71 & 58.93 \\
\hline Industrial & 19 & 33.93 & 92.86 \\
\hline Public & 4 & 7.14 & 100.00 \\
\hline Total & 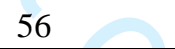 & 100.00 & \\
\hline
\end{tabular}


Table V: Ranking of identified barriers to BIM implementation among contracting firms

\begin{tabular}{|c|c|c|c|c|c|c|c|c|c|c|c|c|}
\hline \multirow{2}{*}{ BIM barriers } & \multicolumn{2}{|c|}{ Small firms } & \multirow[b]{2}{*}{ Rank } & \multicolumn{3}{|c|}{ Medium firms } & \multicolumn{2}{|c|}{ Large firms } & \multirow[b]{2}{*}{ Rank } & \multirow{2}{*}{$\begin{array}{l}\text { Total } \\
\text { Mean }\end{array}$} & \multirow{2}{*}{$\begin{array}{l}\text { Total } \\
\text { Rank }\end{array}$} & \multirow{2}{*}{$\begin{array}{l}\text { Kruskal- } \\
\text { Wallis } \\
\text { Significant }\end{array}$} \\
\hline & Mean & SD & & Mean & S D & Rank & mean & SD & & & & \\
\hline B01. Lack of BIM demand from clients & 4.05 & 1.061 & 25 & 4.09 & 1.005 & 25 & 4.30 & 0.857 & 7 & 4.15 & 23 & 0.4015 \\
\hline B02. Cost of BIM software and its updates & 4.24 & 0.899 & 19 & 4.58 & 0.664 & 2 & 4.55 & 0.642 & 2 & 4.46 & 3 & 0.1595 \\
\hline B03. Cost of the hardware and BIM software & 4.48 & 0.615 & 1 & 4.52 & 0.669 & 6 & 4.53 & 0.602 & 3 & 4.51 & 1 & 0.9314 \\
\hline B04. Cost of BIM training & 4.43 & 0.706 & 5 & 4.19 & 0.921 & 22 & 4.61 & 0.592 & 1 & 4.41 & 5 & 0.1374 \\
\hline $\begin{array}{l}\text { B05. Cost of BIM specialists and additional staff } \\
\text { recruitment }\end{array}$ & 4.29 & 0.774 & 14 & 4.32 & 0.597 & 13 & 3.95 & 0.962 & 20 & 4.19 & 21 & 0.1051 \\
\hline B06. Time frame of BIM application & 4.29 & 0.802 & 15 & 4.33 & 0.748 & 12 & 3.81 & 1.035 & 23 & 4.14 & 24 & $0.0310^{*}$ \\
\hline B07. Investment is not clear from the BIM application & 4.26 & 0.883 & 18 & 4.20 & 1.160 & 21 & 3.71 & 1.058 & 25 & 4.06 & 25 & 0.0869 \\
\hline B08. BIM experts' shortage & 4.46 & 0.678 & 2 & 4.14 & 0.935 & 23 & 4.04 & 0.879 & 16 & 4.21 & 18 & 0.0571 \\
\hline B09. Insufficient BIM standards and protocols & 4.29 & 0.745 & 16 & 4.12 & 0.832 & 24 & 3.80 & 0.980 & 24 & 4.24 & 15 & 0.0624 \\
\hline B10. Belief that there is no need for BIM application & 4.18 & 0.911 & 23 & 4.31 & 0.995 & 15 & 4.23 & 0.732 & 9 & 4.26 & 14 & 0.8813 \\
\hline B11. Interoperability issues & 4.21 & 0.784 & 21 & 4.54 & 0.713 & 3 & 4.03 & 0.869 & 18 & 4.42 & 4 & 0.0692 \\
\hline B12. Weak education and training & 4.16 & 0.731 & 24 & 4.59 & 0.707 & 1 & 4.50 & 0.797 & 4 & 4.33 & 10 & 0.0930 \\
\hline B13. No government efforts to implement BIM & 4.24 & 0.732 & 20 & 4.52 & 0.622 & 7 & 4.22 & 0.953 & 11 & 4.39 & 6 & 0.2532 \\
\hline B14. Difficulty in managing sophisticated data & 4.46 & 0.708 & 3 & 4.52 & 0.669 & 8 & 4.19 & 0.857 & 12 & 4.22 & 16 & 0.2328 \\
\hline B15. Weak cooperation among different professions & 4.45 & 0.766 & 4 & 4.31 & 0.743 & 16 & 3.90 & 0.834 & 21 & 4.22 & 17 & $0.0343 *$ \\
\hline B16. Issues of intellectual property & 4.34 & 0.810 & 10 & 4.31 & 0.743 & 17 & 3.97 & 0.796 & 19 & 4.21 & 19 & 0.2019 \\
\hline B17. BIM design regulations amendment & 4.29 & 0.802 & 17 & 4.28 & 0.957 & 18 & 4.04 & 1.610 & 17 & 4.20 & 20 & 0.3756 \\
\hline B18. Development of BIM forms of contract & 4.32 & 0.720 & 11 & 4.28 & 0.780 & 19 & 3.88 & 0.978 & 22 & 4.16 & 22 & 0.0618 \\
\hline B19. Weak knowledge of BIM benefits & 4.32 & 0.753 & 12 & 4.26 & 0.730 & 20 & 4.33 & 0.710 & 6 & 4.30 & 12 & 0.9461 \\
\hline $\begin{array}{l}\text { B20. Weak skills among professionals and learning } \\
\text { difficulty of BIM software }\end{array}$ & 4.30 & 0.716 & 13 & 4.51 & 0.762 & 9 & 4.24 & 0.727 & 8 & 4.35 & 8 & 0.4704 \\
\hline $\begin{array}{l}\text { B21. Lack of BIM personnel and experts for training BIM } \\
\text { software }\end{array}$ & 4.41 & 0.675 & 7 & 4.45 & 0.671 & 11 & 4.15 & 0.814 & 14 & 4.34 & 9 & 0.2500 \\
\hline $\begin{array}{l}\text { B22. Issues of power supply and weak internet } \\
\text { connectivity }\end{array}$ & 4.21 & 0.694 & 22 & 4.54 & 0.800 & 4 & 4.10 & 0.899 & 15 & 4.28 & 13 & 0.1449 \\
\hline B23. Strong resistance to change & 4.43 & 0.612 & 6 & 4.49 & 0.621 & 10 & 4.17 & 0.702 & 13 & 4.36 & 7 & 0.2254 \\
\hline $\begin{array}{l}\text { B24. BIM requires a complete change of practices and } \\
\text { procedures }\end{array}$ & 4.39 & 0.606 & 8 & 4.32 & 0.649 & 14 & 4.23 & 0.801 & 10 & 4.31 & 11 & 0.6420 \\
\hline B25. Not knowing where to start & 4.39 & 1.046 & 9 & 4.54 & 0.888 & 5 & 4.48 & 0.848 & 5 & 4.47 & 2 & 0.6095 \\
\hline
\end{tabular}

Significant at 5\% 
Table VI: Ranking of identified ways of improving BIM implementation among contracting firms

\begin{tabular}{|c|c|c|c|c|c|c|c|c|c|c|c|c|}
\hline \multirow[t]{2}{*}{ Ways of improving BIM implementation } & \multicolumn{2}{|c|}{ Small firms } & \multirow[b]{2}{*}{ Rank } & \multicolumn{3}{|c|}{ Medium firms } & \multicolumn{2}{|c|}{ Large firms } & \multirow[b]{2}{*}{ Rank } & \multirow{2}{*}{$\begin{array}{l}\text { Total } \\
\text { mean }\end{array}$} & \multirow{2}{*}{$\begin{array}{l}\text { Total } \\
\text { Rank }\end{array}$} & \multirow{2}{*}{$\begin{array}{l}\text { Kruskal -Wallis } \\
\text { Significant }\end{array}$} \\
\hline & Mean & $\mathrm{SD}$ & & Mean & $\mathrm{SD}$ & Rank & Mean & SD & & & & \\
\hline W01.BIM integration into education curricula & 4.65 & 0.483 & 3 & 4.60 & 0.559 & 6 & 4.57 & 0.555 & 4 & 4.61 & 2 & 0.8297 \\
\hline W02. BIM skills development programs & 4.57 & 0.502 & 8 & 4.55 & 0.565 & 8 & 4.67 & 0.481 & 2 & 4.60 & 3 & 0.6747 \\
\hline $\begin{array}{l}\text { W03. Feasible ways of migrating from common } \\
\text { practice into BIM }\end{array}$ & 4.70 & 0.474 & 1 & 4.53 & 0.619 & 9 & 4.37 & 0.641 & 11 & 4.53 & 6 & 0.1008 \\
\hline W04. Increase the availability of BIM technology & 4.65 & 0.494 & 4 & 4.24 & 0.827 & 15 & 4.43 & 0.605 & 10 & 4.43 & 14 & 0.0755 \\
\hline W05. Organized BIM workshops for stakeholders & 4.58 & 0.538 & 6 & 4.63 & 0.651 & 4 & 4.37 & 0.641 & 12 & 4.53 & 7 & 0.2227 \\
\hline $\begin{array}{l}\text { W06.Undertake pilot projects to validate and } \\
\text { demonstrate the BIM benefits }\end{array}$ & 4.50 & 0.615 & 10 & 4.51 & 0.568 & 10 & 4.45 & 0.651 & 8 & 4.49 & 9 & 0.9331 \\
\hline W07. Improvement on BIM interoperability & 4.43 & 0.612 & 13 & 4.64 & 0.549 & 3 & 4.51 & 0.607 & 6 & 4.53 & 8 & 0.3994 \\
\hline $\begin{array}{l}\text { W08.Communicate lessons learnt from the pilots } \\
\text { projects to all stakeholders }\end{array}$ & 4.50 & 0.615 & 11 & 4.60 & 0.660 & 7 & 4.35 & 0.680 & 13 & 4.48 & 10 & 0.3717 \\
\hline $\begin{array}{l}\text { W09. Development of BIM forms of contract for } \\
\text { stakeholders }\end{array}$ & 4.60 & 0.572 & 5 & 4.31 & 0.768 & 14 & 3.99 & 0.826 & 15 & 4.30 & 15 & $0.0040^{*}$ \\
\hline W10. Development of BIM intellectual property & 4.41 & 0.675 & 15 & 4.66 & 0.484 & 1 & 4.28 & 0.861 & 14 & 4.45 & 12 & 0.1027 \\
\hline W11.Improvement on BIM software standardization & 4.57 & 0.576 & 9 & 4.43 & 0.669 & 11 & 4.45 & 0.693 & 9 & 4.48 & 11 & 0.6255 \\
\hline W12. BIM forms of contract with insurance & 4.43 & 0.612 & 14 & 4.36 & 0.751 & 13 & 4.52 & 0767 & 5 & 4.44 & 13 & 0.7054 \\
\hline W13.Educate government departments on 'model & 4.68 & 0.474 & 2 & 4.39 & 0.663 & 12 & 4.61 & 0.552 & 3 & 4.56 & 4 & 0.1346 \\
\hline $\begin{array}{l}\text { based' deliverables and its benefits } \\
\text { W14. Development of BIM warrant }\end{array}$ & 4.49 & 0.615 & 12 & 4.66 & 0.596 & 2 & 4.46 & 0.707 & 7 & 4.54 & 5 & 0.4591 \\
\hline W15. Government enforcement of BIM usage & 4.58 & 0.538 & 7 & 4.61 & 0.657 & 5 & 4.69 & 0.527 & 1 & 4.63 & 1 & 0.6957 \\
\hline
\end{tabular}

Significant at $5 \%$ 


\section{Table VII: Communalities}

\section{BIM Barrier}

B01. Lack of BIM demand from clients B02. Cost of BIM software and its updates B03. Cost of the hardware and BIM software Communalities B04. Cost of BIM training B05. Cost of BIM specialists and additional staff recruitment B06. Time frame of BIM application B07. Investment is not clear from the BIM application B08. BIM experts' shortage B09. Insufficient BIM standards and protocols B10. Belief that there is no need for BIM application B11. Interoperability issues B12. Weak education and training B13. No government efforts to implement BIM B14. Difficulty in managing sophisticated data B15. Weak cooperation among different professions B16. Issues of intellectual property B17. BIM design regulations amendment B18. Development of BIM forms of contract B19. Weak knowledge of BIM benefits B20. Weak skills among professionals and learning difficulty of BIM software B21. Lack of BIM personnel and experts for training BIM software B22. Issues of power supply and weak internet connectivity B23. Strong resistance to change B24. BIM requires a complete change of practices and procedures B25. Not knowing where to start Note: Extraction Method: Principal Component Analysis.

\begin{tabular}{cc} 
Initial & Extraction \\
1.000 & 0.691 \\
1.000 & 0.726 \\
1.000 & 0.589 \\
1.000 & 0.527 \\
1.000 & 0.657 \\
1.000 & 0.630 \\
1.000 & 0.737 \\
1.000 & 0.716 \\
1.000 & 0.550 \\
1.000 & 0.712 \\
1.000 & 0.669 \\
1.000 & 0.640 \\
1.000 & 0.762 \\
1.000 & 0.611 \\
1.000 & 0.622 \\
1.000 & 0.727 \\
1.000 & 0.527 \\
1.000 & 0.660 \\
1.000 & 0.643 \\
1.000 & 0.623 \\
1.000 & 0.636 \\
1.000 & 0.622 \\
1.000 & 0.567 \\
1.000 & 0.738 \\
1.000 & 0.623 \\
& \\
\hline
\end{tabular}


Table VIII: Total variance explained for barriers to BIM implementation in contracting firms

\begin{tabular}{|c|c|c|c|c|c|c|c|c|c|}
\hline \multirow[b]{2}{*}{ Component } & \multicolumn{3}{|c|}{ Initial Eigenvalues } & \multicolumn{3}{|c|}{$\begin{array}{l}\text { Extraction Sums of Squared } \\
\text { Loadings }\end{array}$} & \multicolumn{3}{|c|}{$\begin{array}{l}\text { Rotation Sums of Squared } \\
\text { Loadings }\end{array}$} \\
\hline & Total & $\begin{array}{c}\% \text { of } \\
\text { Variance }\end{array}$ & $\begin{array}{c}\text { Cumulative } \\
\%\end{array}$ & Total & $\begin{array}{c}\% \text { of } \\
\text { Variance }\end{array}$ & $\begin{array}{c}\text { Cumulative } \\
\%\end{array}$ & Total & $\begin{array}{c}\% \text { of } \\
\text { Variance }\end{array}$ & $\begin{array}{c}\text { Cumulative } \\
\%\end{array}$ \\
\hline 1 & 6.007 & 24.027 & 24.027 & 6.007 & 24.027 & 24.027 & 3.716 & 14.863 & 14.863 \\
\hline 2 & 2.962 & 11.846 & 35.873 & 2.962 & 11.846 & 35.873 & 2.633 & 10.530 & 25.393 \\
\hline 3 & 1.833 & 7.333 & 43.206 & 1.833 & 7.333 & 43.206 & 2.396 & 9.583 & 34.976 \\
\hline 4 & 1.612 & 6.449 & 49.655 & 1.612 & 6.449 & 49.655 & 2.260 & 9.039 & 44.015 \\
\hline 5 & 1.531 & 6.123 & 55.778 & 1.531 & 6.123 & 55.778 & 2.008 & 8.031 & 52.046 \\
\hline 6 & 1.240 & 4.960 & 60.738 & 1.240 & 4.960 & 60.738 & 1.803 & 7.213 & 59.259 \\
\hline 7 & 1.195 & 4.779 & 65.517 & 1.195 & 4.779 & 65.517 & 1.564 & 6.257 & 65.517 \\
\hline 8 & 0.989 & 3.955 & 69.472 & & & & & & \\
\hline 9 & 0.915 & 3.660 & 73.132 & & & & & & \\
\hline 10 & 0.883 & 3.533 & 76.665 & & & & & & \\
\hline 11 & 0.775 & 3.099 & 79.764 & & & & & & \\
\hline 12 & 0.724 & 2.897 & 82.661 & & & & & & \\
\hline 13 & 0.594 & 2.375 & 85.036 & & & & & & \\
\hline 14 & 0.530 & 2.118 & 87.154 & & & & & & \\
\hline 15 & 0.446 & 1.783 & 88.938 & & & & & & \\
\hline 16 & 0.425 & 1.700 & 90.638 & & & & & & \\
\hline 17 & 0.405 & 1.621 & 92.259 & & & & & & \\
\hline 18 & 0.365 & 1.460 & 93.719 & & & & & & \\
\hline 19 & 0.358 & 1.431 & 95.150 & & & & & & \\
\hline 20 & 0.311 & 1.243 & 96.393 & & & & & & \\
\hline 21 & 0.258 & 1.031 & 97.424 & & & & & & \\
\hline 22 & 0.192 & 0.767 & 98.191 & & & & & & \\
\hline 23 & 0.181 & 0.724 & 98.915 & & & & & & \\
\hline 24 & 0.151 & 0.603 & 99.519 & & & & & & \\
\hline 25 & 0.120 & 0.481 & 100.000 & & & & & & \\
\hline
\end{tabular}

Note: Extraction Method: Principal Component Analysis 
Table IX: Rotated components matrix of barriers to BIM implementation in contracting firms

\begin{tabular}{|c|c|c|c|c|c|c|c|}
\hline \multirow[t]{2}{*}{ Barriers } & \multicolumn{7}{|c|}{ Principal factors } \\
\hline & 1 & 2 & 3 & 4 & 5 & 6 & 7 \\
\hline B08. BIM experts' shortage & 0.795 & & & & & & \\
\hline B07. Investment is not clear from the BIM application & 0.728 & & & & & & \\
\hline B09. Insufficient BIM standards and protocols & 0.702 & & & & & & \\
\hline B06. Time frame of BIM application & 0.674 & & & & & & \\
\hline B16. BIM design regulations amendment & 0.630 & & & & & & \\
\hline B05. Cost of BIM specialists and additional staff recruitment & 0.505 & & & & & & \\
\hline B17. Development of BIM forms of contract & 0.496 & & & & & & \\
\hline B01. Lack of BIM demand from clients & & 0.773 & & & & & \\
\hline B03. Cost of the hardware and BIM software & & 0.694 & & & & & \\
\hline B02. Cost of BIM software and its updates & & 0.658 & & & & & \\
\hline B04. Cost of BIM training & & 0.625 & & & & & \\
\hline B25. Not knowing where to start & & 0.598 & & & & & \\
\hline B21. Lack of BIM personnel and experts for training BIM software & & & 0.738 & & & & \\
\hline B24. BIM requires a complete change of practices and procedures & & & 0.701 & & & & \\
\hline B23. Strong resistance to change & & & 0.597 & & & & \\
\hline B20. Weak skills among professionals and learning difficulty of BIM software & & & 0.538 & & & & \\
\hline B15. Weak cooperation among different professions & & & & 0.826 & & & \\
\hline B14. Difficulty in managing sophisticated data & & & & 0.674 & & & \\
\hline B19. Weak knowledge of BIM benefits & & & & 0.505 & & & \\
\hline B10. Belief that there is no need for BIM application & & & & & 0.807 & & \\
\hline B16. Issues of intellectual property & & & & & 0.571 & & \\
\hline B13. No government efforts to implement BIM & & & & & & 0.701 & \\
\hline B22. Issues of power supply and weak internet connectivity & & & & & & 0.602 & \\
\hline B12. Weak education and training & & & & & & 0.562 & \\
\hline B11. Interoperability issues & & & & & & & 0.697 \\
\hline
\end{tabular}

